\title{
Enhancing mathematical problem-solving skills of indonesian junior high school students through problem-based learning: A systematic review and meta-analysis
}

\author{
Suparman $^{1 *}$, Yohannes ${ }^{1}$, Nur Arifin ${ }^{1}$ \\ ${ }^{1}$ Universitas Pendidikan Indonesia, Indonesia \\ 函man95@upi.edu*
}

\section{Article Information \\ Submitted January 18, 2021 \\ Revised February 13, 2021 \\ Accepted April 01, 2021}

Keywords

Mathematical Problem-Solving

Skills;

Meta-Analysis;

Problem-Based Learning;

Systematic Review.

\begin{abstract}
Many researchers have conducted previous meta-analysis studies regarding problem-based learning (PBL) to enhance problem-solving skills. However, their research does not focus on mathematical problemsolving skills (MPSS). This study aims to summarize, estimate, and evaluate PBL implementation's effect in enhancing the MPSS of Indonesian junior high school (JHS) students and investigate the study characteristics that affect the heterogeneous effect size data. Twenty-nine relevant primary studies published in national and international journals and proceedings during 2011 - 2020 were analyzed using the systematic review and meta-analysis. The analysis tool used the Comprehensive Meta-Analysis (CMA) software by selecting the formula of Hedge to determine its effect size. The result showed that the overall PBL implementation had a medium positive effect $(g=0,743 ; p<0,05)$, significantly enhancing the MPSS of Indonesian JHS students based on the random effect model. Also, the characteristics of sample size, research area, sampling technique, and publication year did not affect the heterogeneous effect size data. These results suggest that Indonesian JHS mathematics teachers should select PBL as one of the best solutions in implementing mathematics learning in the classroom to enhance students' MPSS.
\end{abstract}

\section{INTRODUCTION}

In this revolution industry 4.0, learning is not only an activity to deal with curriculum goals, but also an activity that must be a focus on improving students' $4 \mathrm{C}$ abilities, which stand for communication, critical thinking, creative thinking, and collaboration or known as the $21^{\text {st }}$ century learning skills. These skills are now crucial to face globalization, anticipate rapid world change, and solve life problems. Problem-solving skills have an important role and become essential in this century (Ince, 2018). Problem-solving skills are mental abilities that require high-order thinking to formulate appropriate problem-solving for everyday problems (Kadir et al., 2013). Mathematics is one of the subjects that concern problem-solving skills. NCTM (National Council of Teachers of Mathematics) stated that problem-solving is one of the standard skills that have to be mastered by students.

There are so many pedagogical models or approaches that can be used in facilitating students' problem-solving skills. The most prominent is Problem-Based Learning (PBL). PBL is a student-centered learning model that sets learning with problems as a prompt to reach learning objectives (Hmelo-Silver, 2004). We can say that the learning process will be running because of the problems that teachers promote. Still, the success of the learning process is depended on the problem provided by teachers. The problem posed by the teacher must be a 
contextual problem that can stimulate students to learn actively and provoke their curiosity to find solutions to these problems. The steps provided by PBL also train students to investigate problems, verify, compile, and evaluate practical solutions of problem-solving both individually and through group discussions (Torp \& Sage, 2002). Thus, PBL can be an alternative learning model that can enhance students' mathematical problem-solving skills (MPSS). Especially in Indonesia, many researchers have tried to examine whether the implementation of PBL has a significant effect in enhancing the MPSS of junior high school (JHS) students. The results of these studies are various. Some said that PBL had a positive effect (Ferdianto et al., 2018; Karatas \& Baki, 2013; Mulyani et al., 2018; Rahmawati et al., 2019; Saragih et al., 2018; Siregar et al., 2018; Sutrisno et al., 2020; Yenni et al., 2017), while others claimed that it had no difference from conventional learning (Amperawan et al., 2018; Hobri et al., 2020; Lestari et al., 2016; Nadhifah \& Afriansyah, 2016; Putri et al., 2018; Rizka et al., 2018; Sa'bani, 2017). Of course, the heterogeneity of the results creates a new problem, especially as the reference for one that believes PBL affected MPSS. Educational policymakers need extensive and comprehensive information on the effect of the implementation of PBL in enhancing the MPSS of JHS students in determining a framework for implementing education in Indonesia. Schools, especially mathematics teachers, also need this information to choose the right alternative learning models that can support learning mathematics in the classroom. Thus, this problem led us to do a more in-depth analysis to summarize all the heterogeneity of the result to gain a good comprehension of the effect of the implementation of PBL in enhancing the MPSS of Indonesian JHS students.

One research method that could integrate various research results with relevant themes was meta-analysis through a systematic review. Meta-analysis is a quantitative-based research method to combine different previous research results to obtain unified information regarding the strength of the effect, correlation, and association between variables (Cumming, 2012), which uses the effect size as an aspect of measurement (Borenstein et al., 2009; Cleophas \& Zwinderman, 2017). Meta-analysis uses quantitative primary research data as a basis for data analysis to extract information to achieve specific research objectives (Glass et al., 1981). Therefore, a meta-analysis was also known as the analytical research method of analysis.

Some researchers have conducted previous research regarding the meta-analysis of the effect of PBL in enhancing students' mathematical abilities. However, mathematical abilities studies are mathematical creative thinking skills (Yunita et al., 2020), mathematical communication skills (Susanti et al., 2020), and mathematical literacy skills (Paloloang et al., 2020), while this meta-analysis study focuses on mathematical problem-solving skills. Metaanalysis study about the effect of PBL on mathematical problem-solving skills has been studied by Suparman et al. (2021). Still, their study focuses on all education levels, such as elementary school, junior high school, senior high school, and college. In contrast, this meta-analysis study only focuses on the junior high school level. A meta-analysis study regarding the effect of PBL on problem-solving skills has been conducted by Kadir et al. (2013) and Park (2019), but their study focuses on mathematics \& science learning and health, while this meta-analysis study only focuses on mathematics learning.

Based on the background, this study aims to summarize, estimate and evaluate the effect of the implementation of PBL in enhancing MPSS of Indonesian JHS students and investigate the characteristics of the study that affect the heterogeneous effect size data. The study's 
urgency is to consider how PBL should ideally be implemented in mathematics subjects, especially for Indonesian students using a systematic review and meta-analysis. This study would provide comprehensive information about the effect of PBL in enhancing JHS students' MPSS in Indonesia. Therefore, it could be a material consideration for education implementers in carrying out an ideal learning process to instill and improve students' thinking skills.

\section{METHODS}

Systematic review and meta-analysis were the methods used in this study. The systematic review and meta-analysis collaboration in this study was because it synthesized various relevant primary studies using quantitative approaches. Systematic review and meta-analysis had several advantages. The advantages include more transparency, detecting and reducing bias, betterestimating population parameters, assessing outcomes in various domains, providing strong evidence of significant rejection, and providing a rigorous methodology in the synthesis process (Littell et al., 2008; Shelby \& Vaske, 2008). In their literature, Bernard et al. (2014); Borenstein et al. (2009); Cooper et al. (2013) and Hunter \& Schmidt (2004) revealed that as a method, the study of systematic review and meta-analysis had several stages, which is shown in the following flowchart in Figure 1.

\section{Defining the problem}

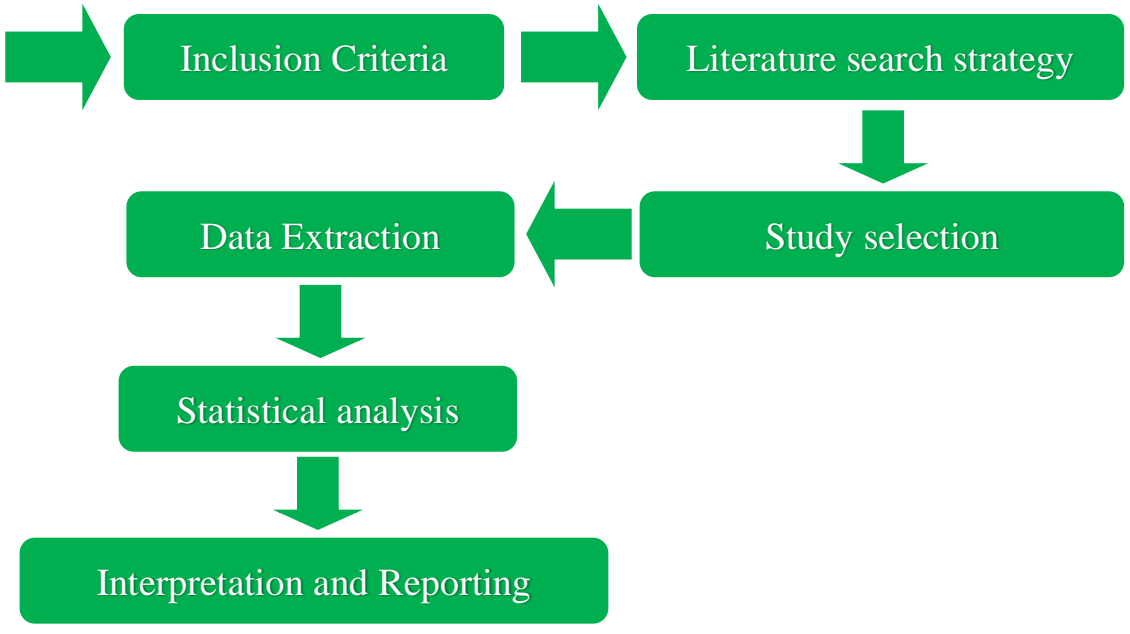

Figure 1. Flow-chart of a systematic review and meta-analysis stages

Therefore, these stages were used in this study. The researchers would explain a few stages in this part, such as inclusion criteria, literature search strategy, data extraction, study selection, and statistical analysis.

\section{Inclusion Criteria}

Preliminary studies regarding the effect of PBL implementation in enhancing MPSS were still comprehensive and general. To make this systematic review and meta-analysis more focused and specific. The inclusion criteria in this study were determined based on the PICOS approach (Population, Interventions, Comparator, Outcomes, and Study Design) (Liberati et al., 2009), namely:

1. The population in the primary study was students at JHS in Indonesia.

2. The intervention in the primary study was the implementation of PBL.

3. The comparator of the intervention in the primary study was the implementation of conventional learning. 
4. The outcome in the primary study was MPSS.

5. The type of research in the primary study was a quasi-experimental research with a causalcomparative type.

6. The primary study reported statistical data such as mean, standard deviation, sample size, $\mathrm{t}$-value, and $\mathrm{p}$-value in both the intervention and comparison groups.

7. The primary study was published in $2010-2020$ in the form of national and international journals and proceedings.

Primary studies that did not meet the inclusion criteria in the study selection process were excluded from this systematic review and meta-analysis.

\section{Literature Search Strategy}

We looked for PBL implementation literature in enhancing Indonesian JHS students' MPSS by using electronic databases such as google scholar, semantic scholar, institute of education science (ERIC), IOP science, and Sinta. The keywords used to look for these kinds of literature were "Problem-Based Learning" and "Mathematical Problem-Solving Skills" or "Mathematical Problem-Solving Abilities." Therefore, databases and keywords could help find and get some primary study that was suitable for the inclusion criteria.

\section{Study Selection}

The inclusion criteria were used as guidelines for selecting primary studies. In their literature, Liberati et al. (2009) suggested that the selection process of the primary study through four stages guided by PRISMA (Preferred Reporting Items for Systematic reviews and MetaAnalysis), namely: (1) identification, (2) screening, (3) eligibility, and (4) included. Thus, this systematic review and meta-analysis used these stages in selecting studies.

\section{Extracting Data}

The researchers extracted data or information such as authors, statistical data (mean, standard deviation, sample size, t-value, and p-value), sampling technique, study area, publication year, and publication type from primary studies that had met the inclusion criteria and gone through the study selection stage. The data extraction process involved two coding experts in systematic review and meta-analysis to ensure that the data or information generated from the extraction process was valid and credible (Vevea et al., 2019). Thus, data or information that was valid and credible provided a chance that the results of this systematic review and meta-analysis were of high quality.

\section{Statistical Analysis}

In this systematic review and meta-analysis, effect sizes were calculated using the Hedge $\mathrm{g}$ equation (Borenstein et al., 2009) because the sample sizes in the intervention group (PBL) were relatively small (Harwell, 2020). The effect size classification developed by Thalheimer $\&$ Cook (2002) was used to interpret the effect sizes obtained. The effect size classification is presented in Table 1. 
Table 1. The Classification of Effect Size in Thalheimer \& Cook's Study

\begin{tabular}{cc}
\hline Effect Size $(\mathrm{ES})$ & Interpretation \\
\hline$-0,15 \leq \mathrm{ES}<0,15$ & Ignored \\
$0,15 \leq \mathrm{ES}<0,40$ & Low \\
$0,40 \leq \mathrm{ES}<0,75$ & Medium \\
$0,75 \leq \mathrm{ES}<1,10$ & High \\
$1,10 \leq \mathrm{ES}<1,45$ & Very High \\
$1,45 \leq \mathrm{ES}$ & Excellent \\
\hline
\end{tabular}

Every publication of the study results was never free from publication bias, so to ensure that the statistical data contained in each primary study was valid, publication bias analysis and sensitivity analysis were critical to being done (Bernard et al., 2014; Furuya-Kanamori \& Doi, 2020). In this meta-analysis study, publication bias analysis used funnel plots, fill and trim test, and the Rosenthal fail-safe $\mathrm{N}$ test (Harwell, 2020). Also, the effect size data's stability and normality were investigated through a sensitivity analysis using the "One study removed" tool in the CMA software (Bernard et al., 2014).

In a meta-analysis study, two types of effect models were used: fixed effect model and random effect model (Borenstein et al., 2009; Mike \& Cheung, 2015). The p-value of the Q Cochran statistic and the heterogeneity analysis's inconsistency value was used to justify the selected effect model in the meta-analysis process and the heterogeneity of the effect size data (Higgins et al, 2003). Heterogenous effect size data indicated that analysis of study characteristics needed to be carried out to investigate further the variables that were likely to cause heterogeneity in effect size data (Borenstein et al., 2009; Siddiq \& Scherer, 2019). Also, the p-value of $Z$ statistics in the null hypothesis analysis was used to justify the significant effect of PBL implementation in enhancing the MPSS of Indonesian JHS students.

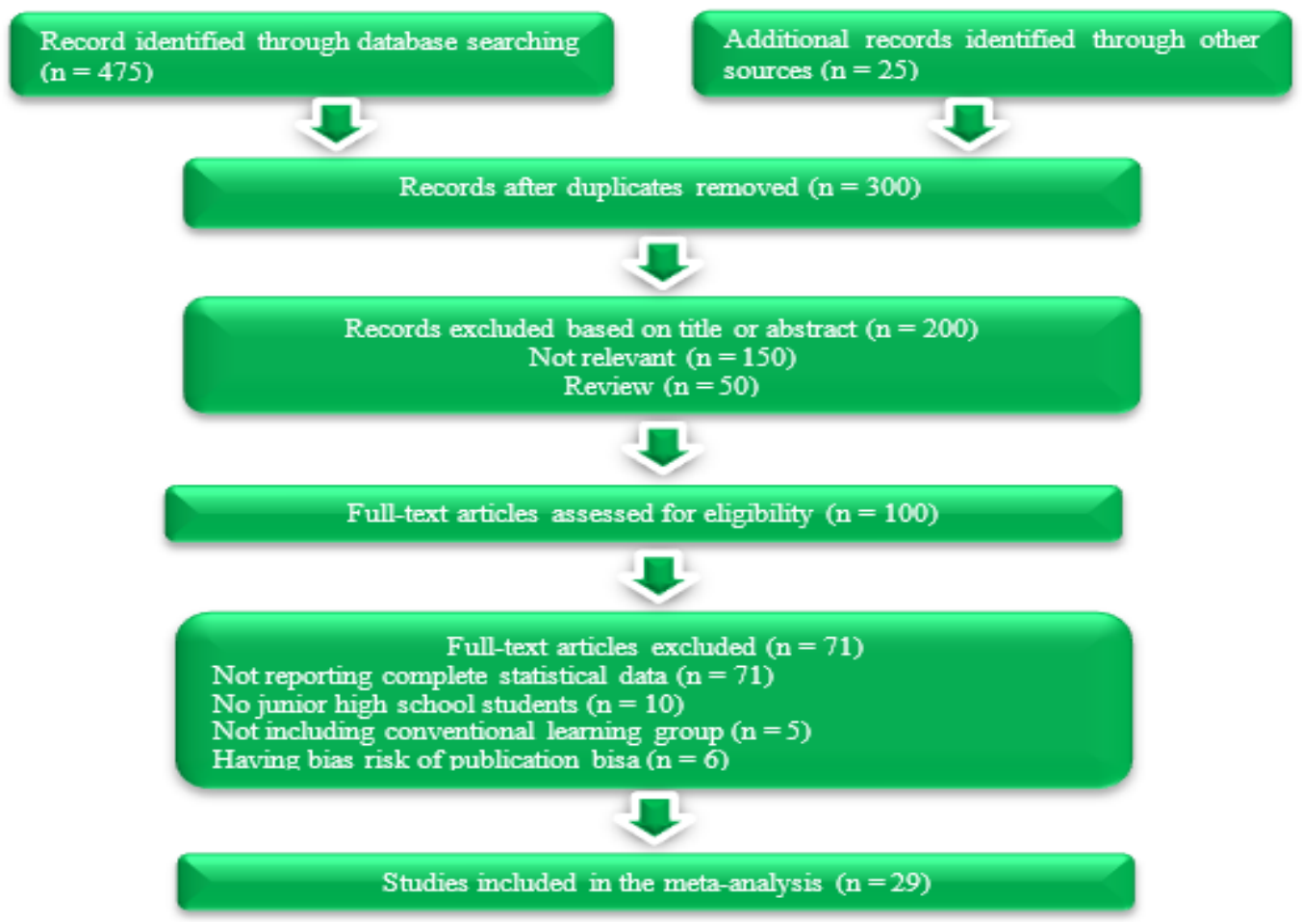

Figure 2. Flowchart for Study Selection 
Suparman, S., Yohannes, Y., \& Arifin, N.

Table 2. The Result of Data Extraction from Twenty-Nine Primary Studies

\begin{tabular}{|c|c|c|c|c|c|c|}
\hline \multirow{3}{*}{ Studies } & \multicolumn{6}{|c|}{ Statistical Data } \\
\hline & \multicolumn{3}{|c|}{ PBL } & \multicolumn{3}{|c|}{ Conventional Learning } \\
\hline & Mean & SS & $\mathrm{SD}$ & Mean & SS & $\mathrm{SD}$ \\
\hline (Saragih et al., 2018) & 38,64 & 38 & 5,69 & 33 & 38 & 5,38 \\
\hline (Siregar et al., 2018) & 29.78 & 23 & 6,74 & 19,40 & 23 & 7,86 \\
\hline (Hobri et al., 2020) & 78,35 & 34 & 11,96 & 58,80 & 34 & 11,84 \\
\hline (Astriani et al., 2017) & 76,94 & 20 & 7,76 & 68,10 & 20 & 10,47 \\
\hline (Yanti, 2017) & 79,73 & 40 & 6,48 & 69,80 & 39 & 6,77 \\
\hline (Miranti et al., 2015) & 77,31 & 30 & 8,89 & 72,30 & 30 & 7,62 \\
\hline (Lestari et al., 2016) & 82,54 & 31 & 7,49 & 76,70 & 31 & 93,75 \\
\hline (Supratinah et al., 2015) & 66,58 & 99 & 18,96 & 55,80 & 98 & 16,21 \\
\hline (Setiawan et al., 2014) & 72,37 & 28 & 9,82 & 66,30 & 28 & 7,43 \\
\hline (Nadhifah \& Afriansyah, 2016) & 0,68 & 40 & 0,25 & 0,75 & 34 & 0,21 \\
\hline (Amperawan et al., 2018) & 13,43 & 30 & 2,35 & 12,40 & 29 & 2,25 \\
\hline (Putri et al., 2018) & 75 & 33 & 16,43 & 68 & 33 & 17,11 \\
\hline (Minarni, 2012) & 13,66 & 71 & 4,38 & 9,97 & 74 & 3,92 \\
\hline (Khayroiyah \& Ramadhani, 2018) & 82,08 & 30 & 9,50 & 76,40 & 30 & 7,99 \\
\hline (Ayu et al., 2016) & 77,53 & 17 & 13,05 & 64,20 & 19 & 13,09 \\
\hline (Afrilia et al., 2014) & 75,60 & 30 & 6,52 & 70,90 & 30 & 4,45 \\
\hline (Elita et al., 2019) & 72,58 & 17 & 8,74 & 65 & 17 & 8,40 \\
\hline (Sa'bani, 2017) & 76,92 & 24 & 11,09 & 71,90 & 26 & 9,35 \\
\hline (Rizka et al., 2018) & 25,58 & 33 & 7,15 & 24,80 & 31 & 4,05 \\
\hline (Aprianti et al., 2018) & 76,92 & 26 & 14,41 & 67,90 & 26 & 10,60 \\
\hline (Laili, 2019) & 84,57 & 42 & 8,16 & 80 & 42 & 8,60 \\
\hline (Zulaiha et al., 2016) & 63,06 & 36 & 18,30 & 41,10 & 36 & 14,08 \\
\hline (Mulyani et al., 2018) & 0,35 & 30 & 0,22 & 0,14 & 60 & 0,10 \\
\hline (Ferdianto et al., 2018) & 0,30 & 25 & 0,21 & 0,21 & 25 & 0,17 \\
\hline (Yenni et al., 2017) & 51,85 & 34 & 28,14 & 31,30 & 34 & 21,36 \\
\hline (Rahmawati et al., 2019) & 73,90 & 28 & 13,38 & 56,40 & 26 & 12,62 \\
\hline (Sutrisno et al., 2020) & 81,91 & 28 & 11,51 & 64,60 & 28 & 15,09 \\
\hline (Karatas \& Baki, 2013) & 9,35 & 26 & 1,55 & 8,16 & 27 & 1,32 \\
\hline
\end{tabular}

\section{RESULTS AND DISCUSSION}

The study's search results identified 475 abstracts from the databases of google scholar, semantic scholar, education resources information center (ERIC), IOP sciences, and Sinta. An additional 25 primary studies were obtained through cited reference tracing of the 475 abstracts. However, it was found that the similar 200 primary studies were not included in the selection process for further studies from the screening results. Then, 200 primary studies were not included in the next study selection process from the remaining 300 primary studies because it was found that 150 primary studies were irrelevant to the title or abstract and 50 primary studies were literature review based on the results of the screening. After that, fifty primary studies did not report statistical data according to the inclusion criteria, ten primary studies whose research subjects were not JHS students, and five primary studies only implied the experiments of PBL without conventional learning of the 100 primary studies that entered the eligibility selection. Therefore, only 35 primary studies were left that met the inclusion criteria. However, it turned out that six primary studies could not be included in the meta-analysis process because they were identified as having a considerable risk of bias through publication bias analysis from the 35 primary studies. Thus, only 29 primary studies corresponded to the inclusion criteria and 
included in this meta-analysis study process. The flowchart of the study selection process in this systematic review and meta-analysis study is presented in Figure 2.

\section{Extracting Data Results}

The twenty-nine primary studies that have fulfilled the inclusion criteria and study selection would be extracted to be some information. The results of data extraction from the twenty-nine primary studies are presented in Table 2 .

\section{Analysis of Publication Bias and Sensitivity}

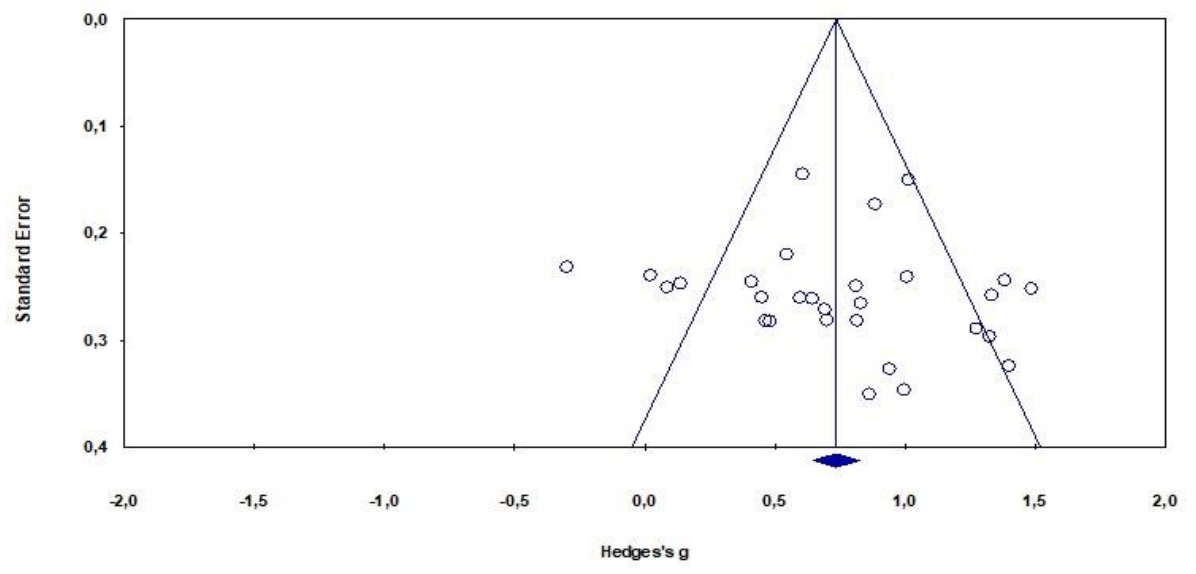

Figure 3. the Funnel Plot of Hedge's Standard Error

The spread of effect size data from the 29 primary studies included in this systematic review and meta-analysis study can be seen in the funnel plot diagram. Figure 3 shows that the distribution of the effect size data from 29 primary studies analyzed in this study was even. The fill and trim test results in Table 3 show that there was no effect size data that should be added or trimmed in this meta-analysis study. This finding interprets strong evidence of the symmetric distribution of effect size data from the 29 primary studies. The results of the fill and trim test are presented in Table 3.

Table 3. The Result of Fill and Trim Test

\begin{tabular}{lcccccc}
\hline & Studies & \multicolumn{2}{c}{ Random Effect Model } & \multicolumn{2}{c}{ Fixed Effect Model } & \multirow{2}{*}{ Q-value } \\
\cline { 3 - 7 } & Trimmed & Hedge's g & $95 \%$ CI & Hedge's g & $95 \%$ CI & \\
\hline Observed Values & & 0,743 & {$[0,583 ; 0,903]$} & 0,734 & {$[0,645 ; 0,822]$} & 87,427 \\
Adjusted values & 0 & 0,743 & {$[0,583 ; 0,903]$} & 0,734 & {$[0,645 ; 0,822]$} & 87,427 \\
\hline
\end{tabular}

Rosenthal's fail-safe $\mathrm{N}$ test in Table 4 shows that this meta-analysis study required 1.909 "null" effect studies such that the combined p-value exceeded $\alpha=0,05$. These findings interpret that the effect size data involved in this meta-analysis process is resistant to publication bias. The results of Rosenthal's fail-safe $\mathrm{N}$ test are presented in Table 4.

Table 4. The Results of Rosenthal's Fail-Safe N Test

\begin{tabular}{lc}
\hline \multicolumn{1}{c}{ Classic Fail-Safe N } \\
\hline Z-value for observed studies & 16,022 \\
The P-value for observed studies & 0,000 \\
Alpha & 0,050 \\
Tails & 2,000 \\
Z for alpha & 1,959 \\
Number of observed studies & 29,00 \\
Number of missing studies that would bring p-value to > alpha & 1.909 \\
\hline
\end{tabular}


Thus, the multiple publication bias analysis conducted provided strong evidence that the effect size data of the 29 primary studies included in this meta-analysis had a low risk of publication bias.

Outliers can play a significant role in the distortion in the averages and the variability of a set of effect sizes. Therefore, sensitivity analysis can be used to identify sources that have the potential to make a collection of abnormal effect sizes (Bernard et al., 2014). In Table 7, it can be seen that the overall effect contained in the random effect model was $\mathrm{g}=0,743 ; 95 \% \mathrm{CI}=$ $[0,583 ; 0,903] ; \mathrm{n}=29 ; \mathrm{SE}=0,08$. By using the tool "One study removed" in CMA software with the random effect model obtained that the highest mean was $\mathrm{g}=0,782 ; \mathrm{n}=29 ; \mathrm{SE}=0,07$ and the lowest mean was $\mathrm{g}=0,716 ; \mathrm{n}=29 ; \mathrm{SE}=0,08$. These results interpret that the collection of effect size is extremely stable and reasonable, which is not affected by an odd combination of effect size and sample size. Thus, it could be concluded that the data of effect size were not sensitive to abnormal effect size and sample size.

\section{Overall Effect Size of Each Primary Study}

The overall effect size of the implementation of PBL in enhancing the MPSS of Indonesian JHS students from each study is presented in Table 5.

Table 5. The Overall Effect Size of Each Primary Study

\begin{tabular}{|c|c|c|c|c|c|c|c|}
\hline \multirow[b]{2}{*}{ Study Name } & \multicolumn{7}{|c|}{ Statistics for Each Study } \\
\hline & $\begin{array}{l}\text { Hedge's } \\
\text { g }\end{array}$ & $\begin{array}{l}\text { Standard } \\
\text { Error }\end{array}$ & $\begin{array}{c}\text { Varian } \\
\text { ce }\end{array}$ & $\begin{array}{l}\text { Lower } \\
\text { Limit }\end{array}$ & $\begin{array}{l}\text { Upper } \\
\text { Limit }\end{array}$ & $\begin{array}{c}\text { Z- } \\
\text { value }\end{array}$ & $\begin{array}{c}\text { P- } \\
\text { value }\end{array}$ \\
\hline (Saragih et al., 2018) & 1,008 & 0,241 & 0,058 & 0,535 & 1,481 & 4,177 & 0,000 \\
\hline (Siregar et al., 2018) & 1,399 & 0,324 & 0,105 & 0,763 & 2,035 & 4,313 & 0,000 \\
\hline (Hobri et al., 2020) & 0,023 & 0,240 & 0,057 & $-0,447$ & 0,493 & 0,096 & 0,924 \\
\hline (Astriani et al., 2017) & 0,941 & 0,327 & 0,107 & 0,299 & 1,582 & 2,874 & 0,004 \\
\hline (Karatas \& Baki, 2013) & 0,816 & 0,282 & 0,080 & 0,263 & 1,368 & 2,892 & 0,004 \\
\hline (Yanti, 2017) & 1,486 & 0,252 & 0,064 & 0,992 & 1,980 & 5,891 & 0,000 \\
\hline (Miranti et al., 2015) & 0,597 & 0,261 & 0,068 & 0,086 & 1,108 & 2,292 & 0,022 \\
\hline (Lestari et al., 2016) & 0,087 & 0,251 & 0,063 & $-0,404$ & 0,579 & 0,349 & 0,727 \\
\hline (Supratinah et al., 2015) & 0,606 & 0,145 & 0,021 & 0,322 & 0,891 & 4,176 & 0,000 \\
\hline (Setiawan et al., 2014) & 0,692 & 0,272 & 0,074 & 0,160 & 1,224 & 2,548 & 0,011 \\
\hline (Nadhifah \& Afriansyah, 2016) & $-0,298$ & 0,232 & 0,054 & $-0,753$ & 0,157 & $-1,283$ & 0,199 \\
\hline (Amperawan et al., 2018) & 0,450 & 0,260 & 0,068 & $-0,060$ & 0,960 & 1,730 & 0,084 \\
\hline (Putri et al., 2018) & 0,411 & 0,246 & 0,060 & $-0,071$ & 0,893 & 1,670 & 0,095 \\
\hline (Minarn & 0,885 & 0,173 & 0,030 & 0,545 & 1,225 & 5,109 & 0,000 \\
\hline (Khayroiyah \& Ramadhani, 2018) & 0,644 & 0,262 & 0,068 & 0,132 & 1,157 & 2,464 & 0,014 \\
\hline (Ayu et al., 2016) & 0,996 & 0,347 & 0,120 & 0,316 & 1,676 & 2,872 & 0,004 \\
\hline (Afrilia et al., 2014) & 0,831 & 0,266 & 0,071 & 0,310 & 1,352 & 3,124 & 0,002 \\
\hline (Elita et al., 2019) & 0,863 & 0,351 & 0,123 & 0,176 & 1,551 & 2,461 & 0,014 \\
\hline (Sa’bani, 2017) & 0,482 & 0,283 & 0,080 & $-0,073$ & 1,036 & 1,703 & 0,089 \\
\hline (Rizka et al., 2018) & 0,138 & 0,247 & 0,061 & $-0,347$ & 0,623 & 0,559 & 0,576 \\
\hline (Aprianti et al., 2018) & 0,700 & 0,282 & 0,079 & 0,148 & 1,252 & 2,485 & 0,013 \\
\hline (Laili, 2019) & 0,546 & 0,220 & 0,049 & 0,114 & 0,978 & 2,479 & 0,013 \\
\hline (Zulaiha et al., 2016) & 1,333 & 0,258 & 0,067 & 0,827 & 1,839 & 5,161 & 0,000 \\
\hline (Mulyani et al., 2018) & 1,383 & 0,244 & 0,060 & 0,904 & 1,862 & 5,658 & 0,000 \\
\hline (Ferdianto et al., 2018) & 0,464 & 0,282 & 0,080 & $-0,089$ & 1,017 & 1,643 & 0,100 \\
\hline (Yenni et al., 2017) & 0,812 & 0,250 & 0,062 & 0,322 & 1,301 & 3,251 & 0,001 \\
\hline i et al., 2019) & 1,325 & 0,297 & 0,088 & 0,742 & 1,907 & 4,458 & 0,000 \\
\hline (Sutrisno et al., 2020) & 1,274 & 0,290 & 0,084 & 0,706 & 1,842 & 4,397 & 0,000 \\
\hline Combined Effect & 0,743 & 0,082 & 0,007 & 0,584 & 0,904 & 9,105 & 0,000 \\
\hline
\end{tabular}


Table 5 shows that the range of effect sizes of the implementation of PBL in enhancing MPSS of Indonesian JHS students was between -0,298 and 1,486. Based on the classification of effect size, one preliminary study had an excellent effect size, five primary studies had a very high effect size, nine primary studies had a high effect size, ten primary studies had a medium effect size, three primary studies had a negligible effect size, and one preliminary study had negative effect size.

To determine the effect size model used, the heterogeneity test was performed. The heterogeneity effect size test calculation results from the primary studies conducted are presented in Table 6.

Table 6. The Heterogeneity Test

\begin{tabular}{lccccc}
\hline \multirow{2}{*}{ Model } & \multirow{2}{*}{ Hedge's g } & \multicolumn{3}{c}{ Heterogeneity } & \multirow{2}{*}{$\mathrm{I}^{2}$} \\
\cline { 3 - 5 } & & Q-value & $\mathrm{df}(\mathrm{Q})$ & $\mathrm{P}$-value & \\
\hline Fixed & 0.734 & 87.43 & 28 & 0.000 & 67.973 \\
Random & 0.743 & & & & \\
\hline
\end{tabular}

The heterogeneity analysis results in Table 6 show that the overall effect size of the primary studies analyzed had a significant difference. The p-value was less than 0,05 in the heterogeneity analysis, which indicates that the random effect model was significantly better than the fixed effect model (Mike \& Cheung, 2015). Therefore, the next process used the random effect model as a basis for conducting the analysis.

To determine whether the implementation of PBL enhances the MPSS of Indonesian JHS students significantly, the analysis of the null hypothesis was conducted. The results of the null hypothesis analysis are presented in Table 7.

Table 7. The Result of the Null Hypothesis Analysis Based on the Random Effect Model

\begin{tabular}{ccccccc}
\hline $\begin{array}{c}\text { Number } \\
\text { Studies }\end{array}$ & Hedge's g & $\begin{array}{c}\text { Standard } \\
\text { Error }\end{array}$ & Variance & $95 \%$ CI & \multicolumn{2}{c}{ Null Hypothesis Test } \\
\cline { 6 - 8 } & & & & Z-value & P-value \\
\hline
\end{tabular}

The null hypothesis test analysis in Table 7 shows that the implementation of PBL significantly enhanced the MPSS of Indonesian JHS students from the 29 primary studies analyzed. The effect size of 29 primary studies analyzed was 0,743 , categorized as a medium effect size. It means that there is a reasonably positive effect of the implementation of PBL in enhancing the MPSS of Indonesian JHS students. This result was in line with the meta-analysis study done by (Dochy et al., 2003), where 43 primary studies were analyzed and concluded that the implementation of PBL was significantly effective in improving students' skills. Parallel to this, Batdi (2014) analyzed 26 primary studies that the implementation of PBL significantly improved students' achievement. As Kadir et al. (2013) stated in their meta-analysis study, it was concluded that PBL implementation on problem-solving skills in mathematics and sciences was categorized as a high effect.

The effect of the implementation of PBL in enhancing JHS students' MPSS in Indonesia was supported theoretically by some experts. One of the characteristics of PBL is a problem as the stimulus in the learning process in the form of a real-world problem (Hung, 2015; Newman, 2005; Savery, 2006). The stimulus will construct flexible knowledge and not depend on procedural knowledge while solving the problem (Hmelo-Silver, 2004). Students will tend to use conceptual understanding to solve the problem until they acquire new information by integrating their prior knowledge. If students regularly do this, they will develop the ability to 
transfer reasoning strategies in further problems, which is a significant PBL indicator (HmeloSilver, 2004). This condition will develop them as self-directed learners and problem solvers, which is the educational objective of this approach (Hung, 2015; Savery, 2006).

The design of PBL builds students' knowledge broadly and flexibly, develops themselves as individuals who can apply their abilities and skills in various conditions, develops practical problem-solving skills, and develops learning skills independently and all-time (Hirça, 2011; Inel \& Balim, 2010; Savery, 2006). The relatively medium effect size of the implementation of PBL in enhancing the MPSS of Indonesian JHS students provides strong evidence that PBL can be used as useful learning in solving the low MPSS of students in learning mathematics. Thus, Indonesian mathematics teachers, especially mathematics teachers at the JHS, can implement PBL as one of the best solutions in enhancing the students' MPSS.

\section{The Analysis of the Study Characteristics}

The heterogeneity of the study characteristics was the factor causing the heterogenous MPSS of Indonesian JHS students from the implementation of PBL. Therefore, it was essential to analyze these factors. The calculation results from the analysis of the study characteristics are presented in Table 8.

Table 8. The Result of Study Characteristics Analysis

\begin{tabular}{|c|c|c|c|c|c|c|c|c|}
\hline \multirow{2}{*}{$\begin{array}{c}\text { Study } \\
\text { Characteristics }\end{array}$} & \multirow{2}{*}{ Group } & \multirow{2}{*}{$\begin{array}{l}\text { Studies } \\
\text { Number }\end{array}$} & \multirow{2}{*}{$\begin{array}{l}\text { Hedge's } \\
\text { g }\end{array}$} & \multicolumn{2}{|c|}{ Null Hypothesis Test } & \multicolumn{3}{|c|}{ Heterogeneity } \\
\hline & & & & Z-value & P-value & $Q_{b}$ & $\mathrm{df}(\mathrm{Q})$ & P-value \\
\hline \multirow{2}{*}{ Sample Size } & $\leq 30$ & 16 & 0,858 & 7,537 & 0,000 & \multirow{2}{*}{2,067} & \multirow{2}{*}{1} & \multirow{2}{*}{0,151} \\
\hline & $>30$ & 13 & 0.625 & 5,396 & 0,000 & & & \\
\hline \multirow{2}{*}{$\begin{array}{l}\text { Sampling } \\
\text { Technique }\end{array}$} & $\begin{array}{l}\text { Random } \\
\text { Sampling }\end{array}$ & 18 & 0,765 & 7,308 & 0,000 & \multirow{2}{*}{0,113} & \multirow{2}{*}{1} & \multirow{2}{*}{0,737} \\
\hline & $\begin{array}{l}\text { Purposive } \\
\text { Sampling }\end{array}$ & 11 & 0,708 & 5,215 & 0,000 & & & \\
\hline \multirow{4}{*}{ Research Area } & $\begin{array}{l}\text { Bali \& Nusa } \\
\text { Tenggara }\end{array}$ & 3 & 0,598 & 2,352 & 0,019 & \multirow{4}{*}{3,032} & \multirow{4}{*}{3} & \multirow{4}{*}{0,387} \\
\hline & Java & 13 & 0,636 & 5,310 & 0,000 & & & \\
\hline & Sumatera & 11 & 0,934 & 6,744 & 0,000 & & & \\
\hline & Kalimantan & 2 & 0,727 & 2,338 & 0,019 & & & \\
\hline Publication & $2010-2015$ & 7 & 0,782 & 4,840 & 0,000 & \multirow{2}{*}{0,077} & \multirow{2}{*}{1} & \multirow{2}{*}{0,781} \\
\hline Year & $2016-2020$ & 22 & 0,730 & 7,517 & 0,000 & & & \\
\hline
\end{tabular}

Four study characteristics were analyzed in this systematic review and meta-analysis study, namely: sample size, sampling technique, research area, and publication year. The pvalue of Q statistics in Table 8 shows that the $\mathrm{p}$-value of all study characteristics was more than 0,05. It means that the heterogeneous effect size of PBL implementation in enhancing the MPSS of Indonesian JHS students is not caused significantly by the characteristics of sample size, sampling technique, research area, and publication year. This finding is similar to the previous meta-analysis study done by Demirel \& Dağyar (2016) and Suparman et al. (2021), where they found no significant difference in the implementation of PBL viewed from the sample size. Another meta-analysis study by Suparman et al. (2021) and Tamur et al. (2020) found no difference in the implementation of RME viewed from publication year. However, the previous meta-analysis study was done by Siddiq \& Scherer (2019) and Tamur et al. (2020) showed that the characteristics of the research area and sampling technique significantly caused the heterogeneous effect size data. The difference between this meta-analysis study and the 
previous meta-analysis study was caused by the difference in the number of primary studies involved in the meta-analysis process.

Based on the sample size, this meta-analysis study divided it to be two groups, namely: sample size, which was less than or equals 30 participants, and sample size, which was more than 30 participants. The null hypothesis test results in Table 8 show that the $\mathrm{p}$-value of $\mathrm{Z}$ statistics of the two sample size groups was less than 0,05. It interprets that the implementation of PBL enhances significantly the MPSS of Indonesian JHS students both of sample size which was less than or equals 30 participants or more than 30 participants. Moreover, PBL implementation in enhancing the MPSS of Indonesian JHS students with a sample size which was less than or equals to 30 is higher than the effect of PBL implementation in enhancing the MPSS of Indonesian JHS students with the sample size which was more than 30 participants. This result is supported by Tamur et al. (2020), where the effect of RME implementation with the sample size, which was less than or equals 31 students, is higher than RME implementation with the sample size, which was more than 31 students. Therefore, descriptively this metaanalysis study suggests to Indonesian JHS mathematics teachers that the implementation of PBL in enhancing the students' MPSS should be applied to classes with a small sample size.

From the characteristics of the sampling technique, this meta-analysis study divided it to be two groups, namely: random sampling and purposive sampling. The $\mathrm{p}$-value of $\mathrm{Z}$ statistics of the two sampling technique groups was less than 0,05. It indicates that the PBL implementation enhances significantly the students' MPSS both of sampling selection using random sampling or purposive sampling. Descriptively, the use of random sampling showed a higher effect than the use of purposive sampling. Siddiq \& Scherer (2019) found a similar result that the use of random sampling was better than the use of convenience sampling. Therefore, random sampling is recommended to know the effect of the implementation of PBL in enhancing the students' MPSS.

Based on the research area's characteristics, this meta-analysis study divided it into four groups: Bali \& Nusa Tenggara, Java, Sumatera, and Kalimantan. The p-value of Z statistics of four research area groups was less than 0,05. It means that the implementation of PBL in Bali \& Nusa Tenggara, Java, Sumatera, and Kalimantan enhances the MPSS of Indonesian JHS students significantly. Also, PBL implementation in enhancing the students' MPSS applied in Sumatera is higher than the effect of PBL implementation in enhancing the students' MPSS applied in Java, Kalimantan, and Bali \& Nusa Tenggara. Thus, it can be interpreted that the implementation of PBL would be appropriated the most, especially in Sumatra and generally in Indonesia.

From the characteristics of publication year, this meta-analysis study divided it to be two groups, namely: primary studies published in 2010 - 2015 and $2016-2020$. The p-value of Z statistics of two publication year groups was less than 0,05 . It shows that the primary studies published in 2010 - 2015 and 2016 - 2020 report that the implementation of PBL enhances the MPSS of Indonesian JHS students significantly. Moreover, primary studies published in 2010 - 2015 and 2016 - 2020 give information that the PBL implementation has a medium effect on students' MPSS. This information suggests to mathematics teachers, especially at the JHS level, that implementing PBL, especially to enhance students' MPSS, should be increased. 


\section{CONCLUSIONS}

The summarization, estimation, and evaluation process of 29 primary studies using systematic review and meta-analysis study provide information that the implementation of PBL has a medium effect size in enhancing the MPSS of Indonesian JHS students. Therefore, this metaanalysis study suggests mathematics teachers in Indonesia select PBL as one of the best solutions to enhance JHS students' MPSS in implementing mathematics learning in the classroom. The heterogeneous effect size of PBL implementation in enhancing students' MPSS is not caused significantly by the characteristics of sample size, sampling technique, research area, and publication year. However, descriptively the investigation of the study characteristics in this meta-analysis study recommends to Indonesian JHS mathematics teachers that the implementation of PBL in enhancing the students' MPSS should be applied to classes with a maximum number of 30 students.

For further systematic review and meta-analysis studies that specifically focus on the implementation of PBL to enhance the students' MPSS, this study suggests that researchers should increase the number of primary studies, databases or literature search engines, and prior primary studies indexed by Scopus. Moreover, the study characteristics such as treatment duration, level of education, and study year should be investigated and analyzed by the next researchers. Therefore, these recommendations and suggestions will make a higher qualified future meta-analysis study.

\section{ACKNOWLEDGMENT}

The writers would like to deliver their gratitude to the Indonesian Endowment Fund of Education (LPDP) for financial support.

\section{AUTHOR CONTRIBUTIONS STATEMENT}

$\mathrm{S}$ worked as the main drafter in this research. Data collection and instrument design assisted by $\mathrm{Y}$ and AN.

\section{REFERENCES}

Afrilia, R., Sutiarso, S., \& Yunarti, T. (2014). Pengaruh model problem-based learning terhadap kemampuan pemecahan masalah matematis siswa. Jurnal Pendidikan Matematika Universitas Lampung, 2(6), 1-9.

Amperawan, I. W., Pujawan, I. G. N., \& Suarsana, I. M. (2018). Komparasi kemampuan pemecahan masalah matematika antara PMR dan PBM pada materi geometri SMP kelas VII. FIBONACCI: Jurnal Pendidikan Matematika Dan Matematika, 4(1), 47-60.

Aprianti, D., Harman, H., \& Yarmayani, A. (2018). Perbandingan kemampuan pemecahan masalah matematis melalui model pembelajaran problem-based learning (PBL) dan model pembelajaran langsung pada siswa kelas VIII SMPN 22 Batanghari. Phi: Jurnal Pendidikan Matematika, 2(2), 94-99.

Astriani, N., Surya, E., \& Syahputra, E. (2017). The effect of problem-based learning to students' mathematical problem-solving ability. IJARIIE, 3(2), 3441-3446.

Ayu, R., Nurrahmawati, N., \& Deswita, H. (2016). Pengaruh model pembelajaran problem- 
based learning (PBL) terhadap kemampuan pemecahan masalah matematika pada siswa kelas VII SMPN 3 Rambah Samo. Jurnal Mahasiswa FKIP Universitas Pasir Pangaraian, 2(2), 1-3.

Batdi, V. (2014). A meta-analysis study comparing problem-based learning with traditional instruction. Electronic Journal of Social Sciences, 13(51), 346-364.

Bernard, R. M., Borokhovski, E., Schmid, R. F., Tamim, R. M., \& Abrami, P. C. (2014). A meta-analysis of blended learning and technology use in higher education: From the general to the applied. Journal of Computing in Higher Education, 26(1), 87-122.

Borenstein, M., Hedges, L. V., Higgins, J. P. T., \& Rothstein, H. R. (2009). Introduction to meta-analysis. John Willey and Son Ltd.

Cleophas, T. J., \& Zwinderman, A. H. (2017). Modern meta-analysis: Review and update of methodologies. Springer International Publishing.

Cooper, H. M., Patall, E. A., \& Lindsay, J. J. (2013). Research synthesis and meta-analysis. In L. Bickman \& D. J. Rog (Eds.), The SAGE handbook of applied social research methods (pp. 344-370). Sage Publications Inc.

Cumming, G. (2012). Understanding the new statistics: Effect sizes, confidence intervals, and meta-analysis. Routledge Taylor \& Francis Group.

Demirel, M., \& Dağyar, M. (2016). Effects of problem-based learning on attitude: A metaanalysis study. EURASIA Journal of Mathematics, Science and Technology Education, 12(8), 2115-2137.

Dochy, F., Segers, M., Van den Bossche, P., \& Gijbels, D. (2003). Effects of problem-based learning: A meta-analysis. Learning and Instruction, 13(5), 533-568.

Elita, G. S., Habibi, M., Putra, A., \& Ulandari, N. (2019). Pengaruh pembelajaran problembased learning dengan pendekatan metakognisi terhadap kemampuan pemecahan masalah matematis. Mosharafa: Jurnal Pendidikan Matematika, 8(3), 447-458.

Ferdianto, F., Caswita, C., \& Asnawati, R. (2018). Pembelajaran berbasis masalah dengan strategi metakognitif dalam meningkatkan kemampuan pemecahan masalah matematis. Jurnal Pendidikan Matematika Universitas Lampung, 6(1), 1-13.

Furuya-Kanamori, L., \& Doi, S. A. R. (2020). Publication bias. In S. Khan (Ed.), Meta-analysis: Methods for health and experimental studies (p. 293). Springer Nature Singapore Pte Ltd.

Glass, G. V., McGaw, B., and Smith, M. L. (1981). Meta-analysis in social research. London: Sage Publication Inc.

Harwell, M. (2020). Growth in the amount of literature reviewed in a meta-analysis and reviewer resources. Mid-Western Educational Researcher, 32(1), 31 - 47.

Higgins, J. P. T., Thompson, S. G., Deeks, J. J., \& Altman, D. G. (2003). Measuring inconsistency in meta-analysis. British Medical Journal, 327, 557-560.

Hirça, N. (2011). Impact of problem-based learning to students and teachers. Asia-Pacific Forum on Science Learning and Teaching, 12(1), 1-19.

Hmelo-Silver, C. E. (2004). Problem-based learning: What and how do students learn? 
Educational Psychology Review, 16(3), 235-266.

Hobri, H., Ummah, I. K., \& Yuliati, N. (2020). The effect of jumping task based on creative problem solving on students' problem solving ability. International Journal of Instruction, 13(1), 387-406.

Hung, W. (2015). Problem-based learning: Conception, practice, and future. In Authentic problem-solving and learning in the 21st century (pp. 75-92). Springer, Singapore.

Hunter, J. E., \& Schmidt, F. L. (2004). Methods of meta-analysis: Correcting error and bias in research findings (2nd ed.). Sage Publications Inc.

Ince, E. (2018). An overview of problem-solving studies in physics education. Journal of Education and Learning, 7(4), 191-200.

Inel, D., \& Balim, A. G. (2010). The effects of using problem-based learning in science and technology teaching upon students' academic achievement and levels of structuring concepts. Asia-Pacific Forum on Science Learning and Teaching, 11(2), 1-23.

Kadir, K., Milama, B., \& Khairunnisa, K. (2013). Meta-analisis efektivitas pendekatan problem-solving dalam pembelajaran sains dan metametika. Lembaga Penelitian UIN Syarif Hidayatullah.

Karatas, I., \& Baki, A. (2013). The effect of learning environments based on problem-solving on students' achievements of problem-solving. International Electronic Journal of Elementary Education, 5(3), 249-267.

Khayroiyah, S., \& Ramadhani, R. (2018). Peningkatan kemampuan pemecahan masalah pada soal cerita matematika menggunakan model PBL berbasis media realistik. Jurnal Matheducation Nusantara, 1(2), 12-17.

Laili, H. (2019). Keefektifan pembelajaran dengan menggunakan pendekatan PBL dan CTL ditinjau dari kemampuan pemecahan masalah dan motivasi belajar. As-Sabiqun: Jurnal Pendidikan Islam Anak Usia Dini, 1(1), 125-141.

Lestari, P. D., Dwijanto, D., \& Hendikawati, P. (2016). Keefektifan model problem-based learning dengan pendekatan saintifik terhadap kemampuan pemecahan masalah dan kemandirian belajar peserta didik kelas VII. Unnes Journal of Mathematics Education, 5(2), 147-153.

Liberati, A., Altman, D. G., Tetzlaff, J., Mulrow, C., Gøtzsche, P. C., Ioannidis, J. P. A., Clarke, M., Devereaux, P. J., Kleijnen, J., \& Moher, D. (2009). The PRISMA statement for reporting systematic reviews and meta-analyses of studies that health care interventions: explanation and elaboration. Journal of clinical epidemiology, 62(10), e1-e34.

Littell, J. H., Corcoran, J., \& Pillai, V. (2008). Systematic review and meta-analysis. Oxford University Press.

Mike, W., \& Cheung, L. (2015). Meta-analysis: A structural equation modeling approach. John Willey and Son Ltd.

Minarni, A. (2012). Pengaruh pembelajaran berbasis masalah terhadap kemampuan pemecahan masalah matematis. Seminar Nasional Matematika Dan Pendidikan Matematika, November, 91-102. 
Miranti, N. ., Agoestanto, A., \& Kurniasih, A. . (2015). Komparasi pembelajaran MEA dan PBL terhadap kemampuan pemecahan masalah dan disposisi matematis siswa SMP kelas VIII pada materi SPLDV. Unnes Journal of Mathematics Education, 4(3), 214-221.

Mulyani, P., Zulyadaini, Z., \& Defitriani, E. (2018). Perbedaan peningkatan kemampuan pemecahan masalah matematis siswa yang memperoleh model pembelajaran kooperatif tipe two stay-two stray (TS-TS) dan model pembelajaran problem-based learning (PBL) di kelas VII SMP Islam Al-Falah Jambi. Phi: Jurnal Pendidikan Matematika, 2(2), 142151.

Nadhifah, G., \& Afriansyah, E. A. (2016). Peningkatan kemampuan pemecahan masalah matematis siswa dengan menerapkan model pembelajaran problem-based learning dan inquiry. Mosharafa: Journal of Mathematics Education, 5(1), 33-44.

Newman, M. J. (2005). Problem-based learning: An introduction and overview of the key features of the approach. Journal of Veterinary Medical Education, 32(1), 12-20.

Paloloang, M. F. B., Juandi, D., Tamur, M., Paloloang, B., \& Adem, A. M. G. (2020). Metaanalisis: Pengaruh problem-based learning terhadap kemampuan literasi matematis siswa di Indonesia tujuh tahun terakhir. AKSIOMA: Jurnal Program Studi Pendidikan Matematika, 9(4), 851-864.

Park, I. (2019). The effect of problem-based learning strategies (PBL) on problem solving skill: a meta-analysis. Journal of The Korean Chemical Society, 10(10), 197-205.

Putri, Y. M., Febriana, R., \& Delyana, H. (2018). Penerapan model problem-based learning (PBL) terhadap kemampuan pemecahan masalah matematis siswa. Seminar Nasional STKIP PGRI Sumatera Barat, 8(1), 44-52.

Rahmawati, T., Yuhana, Y., \& Anriani, N. (2019). Pengaruh problem-based learning terhadap kemampuan pemecahan masalah matematik siswa ditinjau berdasarkan gaya kognitifnya. Jurnal Math Educator Nusantara: Wahana Publikasi Karya Tulis Ilmiah Di Bidang Pendidikan Matematika, 5(1), 80-89.

Rizka, N., Hartoyo, A., \& Suratman, D. (2018). Penerapan model PBL dengan pendekatan metakognitif untuk meningkatkan kemampuan pemecahan masalah matematis siswa SMP. Jurnal Pendidikan Dan Pembelajaran Khatulistiwa, 7(9), 1-9.

Sa'bani, A. (2017). Pengaruh problem-based learning terhadap kemampuan pemecahan masalah matematika siswa. EKUIVALEN-Pendidikan Matematika, 26(1), 18-23.

Saragih, D., Rajagukguk, W., \& Mansyur, A. (2018). The influence of problem-based learning on the mathematical problem-solving and connection ability of students in SMP Swasta Assisi Siantar. IOSR Journal of Research \& Method in Education, 8(2), 24-30.

Savery, J. R. (2006). Overview of PBL: Definitions and distinctions. Interdisciplinary Journal of Problem-Based Learning, 1(1), 9-20.

Setiawan, D., Waluya, S. B., \& Mashuri, M. (2014). Keefektifan PBL berbasis nilai karakter berbantuan CD pembelajaran terhadap kemampuan pemecahan masalah materi segiempat kelas VII. Unnes Journal of Mathematics Education, 3(1), 16-20.

Shelby, L. B., \& Vaske, J. J. (2008). Understanding meta-analysis: A review of the methodological literature. Leisure Sciences, 30(2), 96-110. 
Siddiq, F., \& Scherer, R. (2019). Is there a gender gap? A meta-analysis of the gender differences in students' ICT literacy. Educational Research Review, 27, 205-217.

Siregar, N., Asmin, A., \& Fauzi, M. A. (2018). The effect of problem-based learning model on problem-solving ability student. 3rd Annual International Seminar on Transformative Education and Education Leadership (AISTEEL 2018), 200, 464-467.

Suparman, S., Juandi, D., \& Tamur, M. (2021). Review of problem-based learning trends in 2010-2020 : A meta-analysis study of the effect of problem-based learning in enhancing mathematical problem-solving skills of Indonesian students. Journal of Physics: Conference Series, 1722(012103), 1-9.

Supratinah, U., Budiyono, B., \& Subanti, S. (2015). Eksperimentasi model pembelajaran discovery learning, problem-based learning, dan think-talk write dengan pendekatan saintifik terhadap kemampuan pemecahan masalah matematika ditinjau dari kemandirian belajar siswa. Jurnal Elektronik Pembelajaran Matematika, 3(10), 1138-1149.

Susanti, N., Juandi, D., \& Tamur, M. (2020). The effect of problem-based learning (PBL) model on mathematical communication skills of junior high school students - A meta-analysis study. JTAM (Jurnal Teori dan Aplikasi Matematika), 4(2), 145-154.

Sutrisno, S., Zuliyawati, N., \& Setyawati, R. D. (2020). Efektivitas model pembelajaran problem-based learning dan think pair share berbantuan geogebra terhadap kemampuan pemecahan masalah matematis. Journal of Medives : Journal of Mathematics Education IKIP Veteran Semarang, 4(1), 1-9.

Tamur, M., Juandi, D., \& Adem, A. M. G. (2020). Realistic mathematics education in Indonesia and recommendations for future implementation: A meta-analysis study. Jurnal Teori Dan Aplikasi Matematika, 4(1), 17-27.

Thalheimer, W., \& Cook, S. (2002). How to calculate effect sizes from published research: A simplified methodology. Work-Learning Research, 1, 1-9.

Torp, L., \& Sage, S. (2002). Problems as possibilities: Problem-based learning for $\mathrm{K}-16$ education (2nd ed.). Association for Supervision and Curriculum Development.

Vevea, J. L., Zelinsky, N. A. M., \& Orwin, R. G. (2019). Evaluating coding decisions. In The handbook of research synthesis and meta-analysis (3rd ed). Russel Sage Foundation.

Yanti, A. H. (2017). Penerapan model problem-based learning (PBL) terhadap kemampuan komunikasi dan kemampuan pemecahan masalah matematika siswa SMP Lubuk Linggau. Jurnal Pendidikan Matematika Raflesia, 2(2), 118-129.

Yenni, Y., Mulyani, Y. K., \& Sukmawati, R. (2017). Efektivitas problem-based learning untuk mengoptimalkan kemampuan pemecahan masalah matematis siswa SMP. M A TH L I N E : Jurnal Matematika Dan Pendidikan Matematika, 2(2), 167-178.

Yunita, Y., Juandi, D., Tamur, M., Adem, A. M. G., \& Pereira, J. (2020). A meta-analysis of the effects of problem-based learning on students' creative thinking in mathematics. Beta: Jurnal Tadris Matematika, 13(2), 104-116.

Zulaiha, S., Zubaidah, Z., \& Bistari, B. (2016). Pengaruh model problem-based learning dan motivasi belajar matematika terhadap kemampuan pemecahan masalah matematis. Jurnal Pendidikan Dan Pembelajaran Khatulistiwa, 5(5), 1-15. 